\section{Geology of India}

\author{
Volume 1: By M. Ramakrishnan and \\ $R$. Vaidyanadhan \\ ISBN 978-81-85867-77-9
}

\section{Volume 2: By R. Vaidyanadhan and M. Ramakrishnan}

Geological Society of India, Bangalore 2008, 2 volumes, 1026 pages

India is a vast country; it is the world's second populous nation, with rich mineral and agricultural resources, and an important geopolitical and economic stand. The geology of India is thus significant for science, and geology in India cannot be ignored by educators and policy makers. Indeed, geologic investigations of India date back to the nineteenth century when the Geological Survey of India (the second oldest of its kind in the world) was founded in Calcutta in 1851. Since then, tens of thousands of research papers on India's geology have been published in international and Indian journals, conferences, and book volumes. From time to time, this knowledge has been summarized and synthesized in books, notably, the Geological Survey of India's Manual of Geology of India (four volumes, 1879-1887; one volume, 1893; four volumes, 19501976), D.N. Wadia's Geology of India (fourth edition, 1975), M.S. Krishnan's Geology of India and Burma (sixth edition, 1968), Ravindra Kumar's Fundamentals of Historical Geology and Stratigraphy of India (1985), K.S. Valdiya's Aspects of Tectonics: Focus on South-Central Asia (1984), R. K. Verma's Geodynamics of the Indian Peninsula and the Indian Plate Margin (1991), and S.M. Naqvi's Geology and Evolution of the Indian Plate (2005). The recently published Geology of India joins this noble list. Written by two distinguished Indian geologists, Dr. M. Ramakrishnan and Dr. R. Vaidyanadhan, the book serves both as a handy reference volume and as a university textbook on Indian geology. A book of this nature is usually the outcome of a committed career; therefore, it is apt to introduce the authors as well. M. Ramarkrishnan studied at Presidency College, Chennai (Madras) and Bangalore's Indian Institute of Science, and has a long career of service at the Geological Survey of India and other geosciences-related entities in India. His main field of research
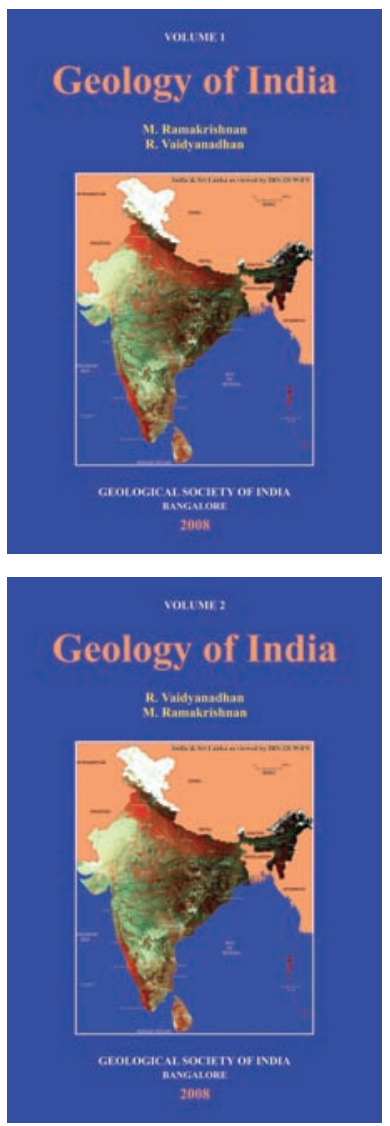

has been the Precambrian geology of southern India. R. Vaidyanadhan graduated from Andhra University, Visakhaptnam, where he also taught geology until 1991. He has mainly worked in the areas of Quaternary geology, geomorphology, and remote sensing. Both authors come from southern India and have been closely associated with the activities of the Geological Society of India which brought out this book in 2008, marking its fiftieth anniversary.

In 13 chapters and nearly 1000 pages, the authors have managed to present a huge amount of information in a systematic manner. Of course, there is always more than one geologic interpretation as we delve into the details of a mapped area, and it is not possible to present all these interpretations and works; the authors have had to be selective and concise. Readers interested in further research can use the book in conjunction with the list of references at the end of each volume.

The first two chapters give an overview of the physiography and geology of India. In chapter 3 , five continental nuclei that constitute the Precambrian Indian Peninsula, that is the Dharwar, Bastar, Singhbhum, Bundelkhand, and Aravalli cratons, are described. This is followed by a chapter on the Precambrian orogenic belts which not only assembled these Indian cratons but also placed India within the supercontinent of Gondwana (or Gondwanaland as originally named by Eduard Suess). The Satpura orogeny or the Central Indian Tectonic Zone united the presently southern and northern Indian cratons, and has been reactivated by various tectonic events during the Phanerozoic. The Pandyan Mobile Belt is manifested in the Palghat-Cauvery shear zone in the southern granulite terrane of India. The Eastern Ghat orogeny joined India with East Antarctica (coeval with the 1,000-Ma Grenvillian orogeny). The latest Proterozoic "Pan African" events in India have been treated here and there in the book while an independent chapter would have painted a coherent picture for this event and period. The Precambrian tectonic events also created over a dozen sedimentary basins which are described in chapter 5 .

Volume 2 of the book deals with the Phanerozoic history of India which is mainly the story of Gondwana, Tethys ocean and stratigraphy, the Deccan Traps, rise of Himalayas, India's Neogene landscape development, and Cenozoic sediments onshore and offshore India. Chapter 12 on the geology of offshore basins along the eastern and western margins of India is timely in view of the recent oil and gas discoveries in these basins. Given the global significance of the Himalaya, an independent chapter on the tectonic evolution of this great mountain range would have been very appropriate.

Overall, figures and illustrations (320 figures and 102 tables) have been well reproduced from the original publications. The hardcover binding and the inclusion of colored maps, although a costly production, has added a great value to the book. The 50-page bibliography, as the authors acknowledge, mostly lists review papers rather than aiming to be detailed (that task itself would have added another volume).

As a final word, we should commend the Geological Society of India and the authors to bring out this useful and informative book on the geology of an important part of our planet. Every library concerned with geology of Asia should have a copy of this book on its shelf.

\section{Rasoul Sorkhabi}

University of Utah,

Energy and Geoscience Institute,

Salt Lake City,

UT 84108, USA.

Email: rsorkhabi@egi.utah 